\title{
ANALISIS ANTESEDEN KEWIRAUSAHAAN DI PERUSAHAAN KELUARGA
}

\author{
Ariyani Wahyu Wijayanti \\ Fakultas Ekonomi, Universitas Veteran Bangun Nusantara Sukoharjo \\ ariyani.fe.univet@gmail.com \\ Salman Faris Insani \\ Fakultas Ekonomi, Universitas Veteran Bangun Nusantara Sukoharjo \\ faris.uvbn@gmail.com
}

\begin{abstract}
This research examines and analyzes the corporate entrepreneurship antecedent in family firms; the willingness to change, generation involvement, perceived technological opportunity, and strategic planning. The samples of this research are family firms which located in the center of batik industry in Surakarta, Sukoharjo, and Sragen. Eighty two respondents in this study are business owners or respective family members who are involved in managing the organization and able to disclose required information for this research. The research used non-probability sampling and purposive sampling as the method and technique. By using multiple regression analysis, the findings have shown that corporate entrepreneurship antecedent is a willingness to change and strategic planning, while generation involvement and perceived technological opportunity do not influence on corporate entrepreneurship.
\end{abstract}

Keywords: corporate entrepreneurship, strategic planning, family firm.

\begin{abstract}
ABSTRAK
Penelitian ini menguji dan menganalisis anteseden kewirausahaan perusahaan di perusahaan keluarga, yaitu kemauan untuk berubah, keterlibatan generasi, peluang teknologi yang dipersepsikan, serta perencanaan strategis. Sampel dalam penelitian ini adalah perusahaan keluarga di sentra batik wilayah Surakarta, Sukoharjo dan Sragen. Responden dalam penelitian ini adalah pemilik dan atau anggota keluarga yang terlibat dalam pengelolaan perusahaan yang berjumlah 82 responden. Metoda sampling yang digunakan adalah nonprobability sampling, sedangkan teknik yang dipakai adalah purposive sampling. Analisis data menggunakan regresi berganda. Hasil analisis yang dapat disimpulkan dari penelitian ini yaitu anteseden dari kewirausahaan perusahaan adalah kemauan untuk berubah dan perencanaan strategis, sedangkan keterlibatan generasi dan peluang teknologi yang dipersepsikan tidak berpengaruh pada kewirausahaan perusahaan.
\end{abstract}

Kata Kunci: Kewirausahaan perusahaan, perencanaan strategis, perusahaan keluarga. 


\section{PENDAHULUAN}

Perusahaan keluarga memiliki peran penting bukan hanya karena perusahaan keluarga memberikan kontribusi penting bagi perekonomian, tetapi juga karena memiliki stabilitas jangka panjang (Top et al., 2013). Perusahaan keluarga didefinisikan sebagai perusahaan yang dimiliki dan dibangun keluarga untuk dapat bertahan lebih dari satu generasi dengan keterlibatan tinggi dari anggota keluarga dalam menjalankan bisnis (Kellermanns et al., 2008). Uhlaner et al. (2012) disisi lain menyatakan bahwa tingkat kewirausahaan dalam perusahaan keluarga masih menjadi bahan perdebatan di kalangan peneliti. Kewirausahaan dipandang sebagai faktor penting dalam kelangsungan hidup perusahaan keluarga karena membantu menciptakan lapangan kerja dan kekayaan untuk anggota keluarga (Kellermanns dan Eddleston 2006). Carney (2005) di sisi lain menyatakan bahwa kontrol keluarga berpotensi menjadi kendala yang dapat menghambat perusahaan keluarga dari kegiatan kewirausahaan, sehingga keputusan untuk berinvestasi dalam kewirausahaan tidak selalu sederhana untuk perusahaan keluarga. Short et al. (2009) menyatakan bahwa perusahaan keluarga memiliki karakteristik unik yang berasal dari pola kepemilikan, tata kelola dan suksesi yang semuanya itu dapat mempengaruhi kinerja perusahaan. Keberagaman pendapat tersebut menunjukkan adanya urgensi untuk meneliti kewirausahaan dalam perusahaan keluarga dengan mempertimbangkan nilainilai dan sikap anggota keluarga.

Penelitian yang dilakukan oleh Miller (1983) mengemukakan beberapa faktor yang mempengaruhi perilaku kewirausahaan di level perusahaan, yaitu kemauan untuk berubah (willingness to change), keterlibatan generasi (generational involvement), peluang teknologi yang dipersepsikan (perceived technological opportunities), serta perencanaan strategis (strategic planning). Pemikiran mengenai kewirausahaan dalam perusahaan keluarga muncul karena dipengaruhi oleh sejauh mana anggota keluarga yang terlibat dalam pengelolaan perusahaan mau berubah dan terbuka untuk ide-ide baru dan kemampuan untuk melihat peluang teknologi dalam lingkungannya. Salvato (2004) juga mengatakan bahwa jumlah generasi yang terlibat dalam pengelolaan perusahaan keluarga serta perencanaan strategis memainkan peranan penting dalam jalannya perusahaan keluarga. Hal ini sejalan dengan hasil penelitian yang dilakukan oleh Kellermanns et al. (2008) yang menunjukkan bahwa keterlibatan generasi berpengaruh positif kewirausahaan perusahaan. Beberapa penelitian mengenai kewirausahaan perusahaan juga menunjukkan hasil bahwa kemauan untuk berubah, peluang teknologi yang dipersepsikan, serta perencanaan strategis merupakan faktor yang mempengaruhi kewirausahaan perusahaan (Eser et al., 2012; Kellermanns \& Eddleston, 2006; Weismeier-Sammer, 2011).

Penelitian ini menguji pengaruh faktor-faktor yang berpengaruh terhadap kewirausahaan perusahaan, yang terdiri dari: kemauan untuk berubah, keterlibatan generasi, peluang teknologi yang dipersepsikan, serta perencanaan strategis, khususnya dalam konteks perusahaan keluarga dengan mengambil obyek penelitian perusahaan keluarga di sentra batik wilayah Surakarta, Sukoharjo dan Sragen. Batik 
merupakan salah satu warisan budaya yang telah diakui UNESCO pada tanggal 30 September 2009, menjadi bagian dari 76 warisan budaya tak benda. Perdagangan batik semakin berkembang setelah memperoleh pengakuan dari UNESCO. Perkembangan ini juga terjadi di Solo Raya (termasuk sentra batik di Kabupaten Sragen, Wonogiri, Bekonang, Klaten dan Sukoharjo) sebagai pusat produksi batik tradisional (Hatiningsih 2012). Hal ini menunjukkan adanya urgensi dari eksistensi usaha batik yang merupakan perusahaan keluarga sekaligus sebagai warisan budaya Indonesia untuk mengembangkan perilaku kewirausahaan agar dapat berkembang dari generasi ke generasi. Berdasarkan data Kementerian Perindustrian dalam lima tahun sejak 2011-2015, industri batik tumbuh 14,7 persen dari 41.623 unit menjadi 47.755 unit. Industri batik terbukti dapat menyerap tenaga kerja mencapai 900 ribu orang dengan nilai produksi mencapai USD 39,4 Juta

\section{KAJIAN PUSTAKA DAN PERUMUSAN HIPOTESIS}

Kewirausahaan perusahaan (corporate entrepreneurship) merupakan konsep yang telah dipelajari secara luas dalam beberapa dekade terakhir, khususnya dalam keterkaitannya dengan inovasi dan daya saing jangka panjang dari perusahaan (Hitt et al., 1999). Borch et al. (1999) mendefinisikan kewirausahaan perusahaan sebagai perusahaan yang memiliki strategi yang berkaitan dengan inovasi dan pertumbuhan, yang ditandai dengan keberanian untuk mengambil risiko. Keberadaan dari kewirausahaan perusahaan menurut Miller (1983) ditandai dengan adanya dengan inovasi produk maupun pasar, perhatian di bidang teknologi, pengambilan risiko dan sikap proaktif.

Perusahaan keluarga didefinisikan oleh Simanjuntak (2010) sebagai perusahaan yang dimiliki dan/atau dikelola oleh sejumlah orang yang memiliki hubungan kekeluargaan, baik suami-istri maupun keturunannya, termasuk hubungan persaudaraan. Kellermanns dan Eddleston (2006) menyatakan bahwa kewirausahaan perusahaan merupakan elemen penting dalam kelangsungan hidup perusahaan keluarga karena peran krusialnya dalam penciptaan lapangan kerja dan pengembangan aset dari anggota keluarga. Kelangsungan hidup, profitabilitas dan kemajuan sebuah perusahaan keluarga menurut Salvato (2004) di pengaruhi oleh kewirausahaan perusahaan atau corporate entrepreneurship.

\section{Kemauan untuk Berubah}

Kemauan untuk berubah menurut Weismeier-Sammer (2011) ditandai dengan adanya budaya yang terbuka terhadap inovasi dan peluang untuk melakukan perubahan dalam rangka mempertahankan daya saing perusahaan. Penelitian yang dilakukan oleh Eser et al. (2012) yang diterapkan pada 128 perusahaan mikro di Istanbul (Turki) menunjukkan adanya peran krusial dari kemauan untuk berubah sebagai prediktor dari kewirausahaan perusahaan. Penelitian yang dilakukan oleh Kellermanns dan Eddleston (2006) serta Weismeier-Sammer (2011) menunjukkan bahwa kemauan untuk berubah memiliki pengaruh positif pada kewirausahaan 
perusahaan. Miller (1983) menyatakan bahwa perilaku kewirausahaan dalam perusahaan keluarga bergantung pada keterbukaan anggota keluarga sebagai pengelola pada ide-ide baru dan kemauan mereka melakukan perubahan demi kemajuan perusahaan. Hipotesis yang dirumuskan dalam penelitian ini adalah:

H1: Kemauan untuk berubah memiliki pengaruh positif pada kewirausahaan perusahaan.

\section{Keterlibatan Generasi}

Keterlibatan Generasi menurut Chirico dan Sirmon (2010) mengacu pada jumlah generasi keluarga yang secara bersamaan terlibat dalam manajemen perusahaan. Penelitian yang dilakukan Salvato (2004) menyarankan adanya peran keterlibatan generasi yang mempengaruhi kegiatan kewirausahaan dalam konteks perusahaan keluarga, dengan asumsi bahwa tingkat perilaku dalam perusahaan keluarga berbeda antar generasi. Fenomena yang sering ditemui dalam perusahaan keluarga adalah pendiri mempunyai fokus pada usaha keras agar perusahaan dapat berkembang dan bertahan. Perusahaan kemudian mulai tumbuh menjadi lebih besar dan kuat dan mulai memasuki tahapan generasi kedua dan extended family, termasuk anak, saudara-saudara, keponakan dan cucu dan membentuk the dynasty of family (Majalah Eksekutif, 2014). Hal ini tidak jauh berbeda dengan hasil penelitian dari Kellermanns dan Eddleston (2006) yang menunjukkan meskipun pendiri perusahaan keluarga bersedia mengambil risiko yang terkait dengan memulai usaha, keinginan mereka untuk menjaga bisnis dalam keluarga dan menjaga kekayaan keluarga bisa membatasi mereka dari mengambil risiko yang terkait dengan kewirausahaan perusahaan. Hal ini didukung oleh Kellermanns et al. (2008) yang menyatakan bahwa keterlibatan beberapa generasi dapat meningkatkan perilaku kewirausahaan karena generasi yang lebih baru mungkin menjadi kekuatan pendorong untuk perubahan dan inovasi dan mereka juga mungkin lebih mungkin untuk melihat pentingnya perilaku kewirausahaan untuk kelangsungan hidup jangka panjang perusahaan. Hipotesis yang dirumuskan dalam penelitian ini adalah:

H2: Keterlibatan generasi memiliki pengaruh positif pada kewirausahaan perusahaan.

\section{Peluang Teknologi yang Dipersepsikan}

Kellermanns dan Eddleston (2006) mendefinisikan peluang teknologi yang dipersepsikan sebagai kemampuan perusahaan untuk melihat peluang perkembangan dalam industri melalui inovasi produk dan proses. Peluang teknologi berdasarkan definisi dari Zahra (1996) mengacu pada sejauh mana perusahaan keluarga melihat industri mereka berkembang berkat adanya kesempatan untuk melakukan inovasi dengan memanfaatkan teknologi. Penelitian yang dilakukukan oleh Kellermanns dan Eddleston (2006) serta Weismeier-Sammer (2011) menunjukkan bahwa peluang teknologi yang dipersepsikan memiliki pengaruh positif pada kewirausahaan perusahaan. Eser et al. (2012) menyatakan bahwa perusahaan keluarga yang mampu mengoptimalkan keberadaan dari peluang penggunaan teknologi cenderung dapat meningkatkan kemampuan kewirausahaan perusahaan. Oleh karena itu, kemampuan 
perusahaan keluarga untuk melihat peluang teknologi dalam lingkungannya dapat menjadi faktor penentu yang membedakan perusahaan keluarga yang memiliki kewirausahaan perusahaan tinggi dengan perusahaan keluarga yang memiliki kewirausahaan perusahaan rendah. Hipotesis yang dirumuskan dalam penelitian ini adalah:

H3: Peluang teknologi yang dipersepsikan memiliki pengaruh positif pada pada kewirausahaan perusahaan.

\section{Perencanaan Strategis}

Kudla (1980) mendefinisikan perencanaan strategis sebagai sebuah proses yang sistematis untuk menentukan tujuan dan sasaran perusahaan untuk setidaknya tiga tahun ke depan dan mengembangkan strategi yang akan mengatur penggunaan sumber daya untuk mencapai tujuan tersebut. Sirmon dan Hitt (2003) menyatakan bahwa perusahaan keluarga harus mengelola sumber daya dan melakukan perencanaan strategis untuk meraih kesuksesan di masa depan dalam lingkungan yang kompetitif. Penelitian yang dilakukan Eser et al. (2012) dalam konteks perusahaan mikro di Istanbul (Turki) sejumlah 128 perusahaan menunjukkan adanya pengaruh positif dari perencanaan strategis terhadap kewirausahaan perusahaan. Riset yang dilakukan oleh Kellermanns dan Eddleston (2006) menunjukkan bahwa perencanaan strategis berkontribusi pada kewirausahaan perusahaan dalam perusahaan keluarga. Perusahaan keluarga yang memiliki tingkat perilaku kewirausahaan yang lebih tinggi, memiliki strategi yang berimplikasi pada orientasi kewirausahaan. Adanya tujuan yang jelas dalam perusahaan akan meningkatkan semangat kewirausahaan pengelolanya. Hipotesis yang dirumuskan dalam penelitian ini adalah:

H4: Perencanaan strategis memiliki pengaruh positif pada pada kewirausahaan perusahaan.

Berdasarkan hipotesis yang dirumuskan, pengaruh antar variabel dapat digambarkan dalam bentuk model penelitian sebagai berikut:

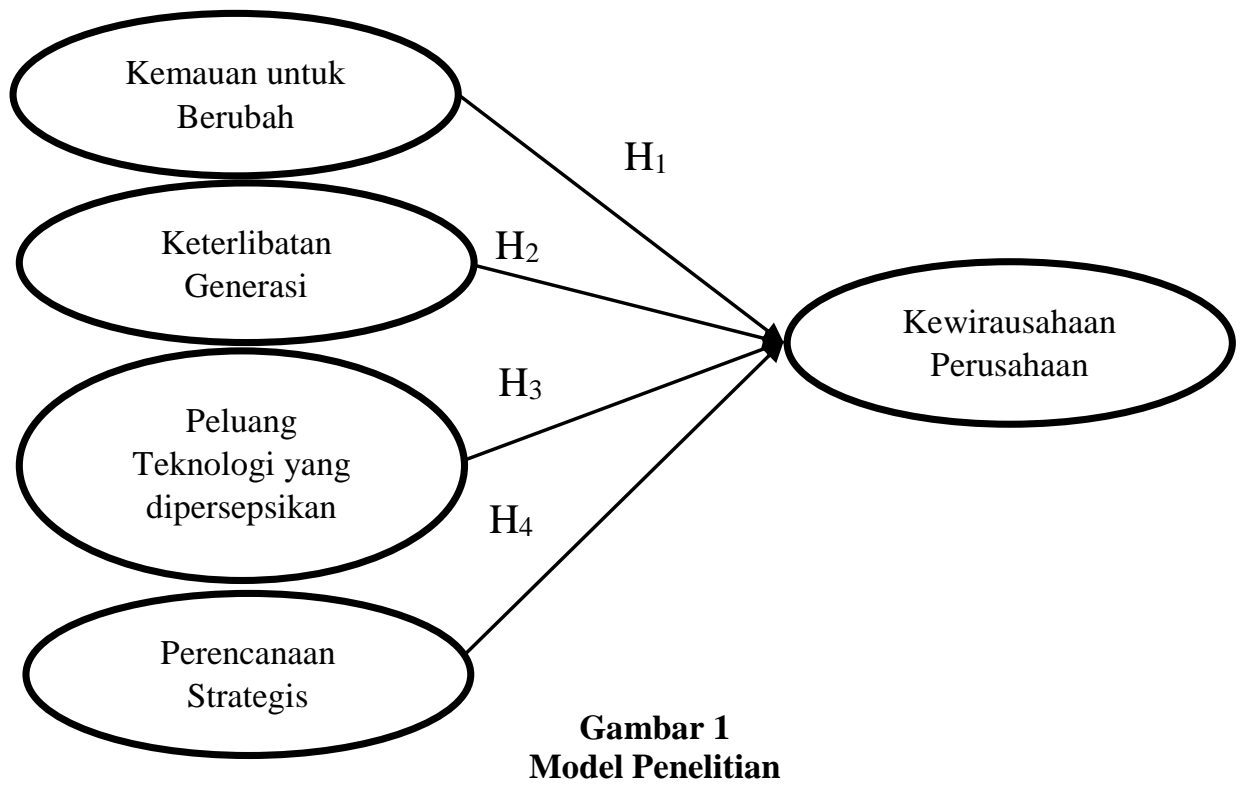




\section{METODA PENELITIAN}

\section{Populasi dan Sampel}

Populasi dalam penelitian ini adalah semua perusahaan di sentra batik wilayah Surakarta, Sukoharjo dan Sragen. Sampel dalam penelitian ini adalah perusahaan keluarga di sentra batik wilayah Surakarta, Sukoharjo dan Sragen yang minimal ada 2 anggota keluarga terlibat dalam pengelolaan, telah berdiri minimal 3 tahun dan termasuk perusahaan manufaktur (melakukan produksi sampai dengan pemasaran) serta memiliki merek dagang sendiri. Adapun yang menjadi responden dalam penelitian ini adalah pemilik dan atau anggota keluarga yang terlibat dalam pengelolaan perusahaan dan dapat memberikan informasi yang dibutuhkan dalam penelitian ini serta bersedia untuk menjadi responden. Untuk memperoleh data yang diperlukan, peneliti melakukan penyebaran kuesioner. Total kuesioner yang diedarkan sebanyak 120 kuesioner. Kuesioner yang kembali dan digunakan dalam penelitian ini sebanyak 82 kuesioner. Karakteristik sampel disajikan pada Tabel 1.

Tabel 1

Karakteristik Sampel

\begin{tabular}{ccc}
\hline & Karakteristik & \% \\
\hline Lama Berdiri & $3-14$ tahun & 61 \\
& $15-26$ tahun & 30,5 \\
& $27-38$ tahun & 6,1 \\
& $39-50$ tahun & 2,4 \\
\hline Lokasi & Kota Surakarta & 32,9 \\
Perusahaan & Kabupaten Sukoharjo & 15,9 \\
& Kabupaten Sragen & 51,2 \\
\hline Ukuran & Mikro & 7,3 \\
Perusahaan & Kecil & 48,8 \\
& Menengah & 39 \\
& Besar & 4,9 \\
\hline
\end{tabular}

\section{Definisi Operasional dan Pengukuran Variabel}

Untuk memberikan gambaran dan pemahaman yang lebih baik, maka berikut ini akan disampaikan definisi operasional dari masing-masing variabel yang berkaitan dan akan dibahas dalam penelitian ini. Setiap item pernyataan yang digunakan dalam penelitian ini dinilai dengan menggunakan skala Likert dengan 5 alternatif pilihan, yaitu Sangat Tidak Setuju (STS), Tidak Setuju (TS), Netral (N), Setuju (S) dan Sangat Setuju (SS); kecuali yang disebutkan lain.

1. Kewirausahaan Perusahaan

Kewirausahaan perusahaan adalah berbagai aktivitas potensial termasuk inovasi produk, pengambilan risiko dan sikap proaktif yang bertujuan untuk memfasilitasi pembaharuan dan keberlanjutan perusahaan. Pengukuran variabel kewirausahaan keluarga dilakukan dengan 7 item pernyataan berdasarkan dari penelitian Kellermanns dan Eddleston (2006) serta Weismeier-Sammer (2011). Tiga item mengenai pengenalan produk baru dan tingkat inovasi perusahaan, dua 
item terkait dengan kecenderungan perusahaan untuk proyek-proyek berisiko tinggi dan tindakan yang dilakukan untuk posisi diri di masing-masing pasar, dan dua item terkait dengan komitmen perusahaan untuk penelitian dan pengembangan serta strategi inovasi perusahaan.

2. Kemauan untuk Berubah

Kemauan untuk berubah adalah kesiapan anggota keluarga sebagai pengelola perusahaan keluarga untuk menghadapi tantangan baru dalam bisnis, keterbukaan mereka untuk mencoba hal baru dan ketertarikan mereka secara umum terhadap ide-ide baru yang muncul. Pengukuran variabel kemauan untuk berubah dilakukan dengan 4 item pernyataan berdasarkan dari penelitian Kellermanns dan Eddleston (2006) serta Weismeier-Sammer (2011). Responden diminta untuk menilai kesiapan perusahaan untuk menghadapi tantangan baru dalam bisnis, keterbukaan untuk mencoba hal-hal baru, dan daya tarik yang timbul dari ide-ide baru.

3. Keterlibatan Generasi

Keterlibatan generasi diukur dengan 1 item berdasarkan dari penelitian Kellermanns dan Eddleston (2006) serta Weismeier-Sammer (2011). Responden diminta untuk menentukan jumlah generasi saat ini yang terlibat dalam pengelolaan bisnis keluarga (satu, dua, atau beberapa generasi).

4. Peluang Teknologi yang dipersepsikan

Peluang teknologi yang dipersepsikan adalah kemampuan anggota keluarga sebagai pengelola perusahaan keluarga melihat peluang untuk inovasi, penelitian dan pengembangan dalam satu industri. Pengukuran variabel peluang teknologi yang dipersepsikan dilakukan dengan 4 item pernyataan berdasarkan dari penelitian Kellermanns dan Eddleston (2006) serta Weismeier-Sammer (2011). Keempat item tersebut digunakan untuk mengukur persepsi responden tentang peluang untuk inovasi produk, inovasi teknologi dan terobosan teknologi yang ada dalam industri batik, serta tingkat penelitian dan pengembangan di industri batik dibandingkan dengan industri lainnya.

5. Perencanaan Strategis

Perencanaan strategis merupakan pengembangan rencana jangka panjang yang meliputi menentukan misi perusahaan, menentukan tujuan-tujuan yang dapat dicapai, pengembangan strategi dan penetapan pedoman kebijakan. Pengukuran variabel perencanaan strategik dilakukan dengan 4 item pernyataan berdasarkan dari penelitian Kellermanns dan Eddleston (2006) serta Weismeier-Sammer (2011). Dua item digunakan untuk mengukur tingkat upaya perencanaan strategis dalam bisnis. Item ketiga menanyakan apakah responden tahu apa yang harus dilakukan untuk mencapai tujuan bisnis mereka, dan item keempat responden ditanya mengenai apakah perusahaan mempunyai tujuan yang jelas. 


\section{ANALISIS DAN PEMBAHASAN}

\section{Hasil Uji Instrumen Penelitian}

Pengujian validitas dilakukan pada empat variabel utama dalam penelitian ini, yaitu kemauan untuk berubah, peluang teknologi yang dipersepsikan, perencanaan strategis dan kewirausahaan perusahaan. Sedangkan variabel keterlibatan generasi tidak diuji validitas karena merupakan observe variable bukan variabel laten yang memerlukan indikator. Hasil uji validitas menunjukkan terdapat 2 item yang tidak valid sehingga dihilangkan dari analisis, yaitu 1 item pernyataan kewirausahaan perusahaan dan 1 item pernyataan kemauan untuk berubah.

Uji reliabilitas yang dilakukan didapatkan hasil yaitu: reliabilitas kemauan untuk berubah sebesar 0,623; reliabilitas peluang teknologi yang dipersepsikan sebesar 0,798, reliabilitas perencanaan strategis 0,827 dan reliabilitas kewirausahaan perusahaan sebesar 0,737 .

\section{Hasil Uji Hipotesis}

Penelitian ini menggunakan metoda multiple regression analysis (analisis regresi berganda) untuk menguji hipotesis yang diajukan dalam penelitian ini. Tabel 2 menunjukkan hasil pengujian kemauan untuk berubah, keterlibatan generasi, peluang teknologi yang dipersepsikan, serta perencanaan strategis sebagai variabel independen yang diregresikan pada kewirausahaan perusahaan sebagai variabel dependen. Terdapat dua variabel yang berpengaruh pada kewirausahaan perusahaan, yaitu kemauan untuk berubah dan perencanaan strategis, sehingga $\mathrm{H} 1$ dan $\mathrm{H} 4$ didukung dalam penelitian ini; sedangkan variabel keterlibatan generasi dan peluang teknologi yang dipersepsikan tidak berpengaruh pada kewirausahaan perusahaan, sehingga H2 dan $\mathrm{H} 3$ tidak didukung dalam penelitian ini.

Tabel 2

Hasil Uji Multiple Regression Analysis

\begin{tabular}{lccc}
\hline \multicolumn{4}{c}{ Hasil Uji Multiple Regression Analysis } \\
& \multicolumn{3}{c}{ Kewirausahaan Perusahaan } \\
& $\boldsymbol{\beta}$ & $\mathbf{T}$ & Sig \\
\hline Kemauan untuk berubah (KB) & 0,238 & 2,240 & 0,028 \\
Keterlibatan generasi (KG) & $-0,058$ & $-0,547$ & 0,586 \\
Peluang teknologi yang dipersepsikan & 0,156 & 1,424 & 0,158 \\
(PT) & & & \\
Perencanaan strategis (PS) & 0,289 & 2,401 & 0,019 \\
$\mathrm{R}^{2}$ & & & \\
Adjusted $\mathrm{R}^{2}$ & & & 0,256 \\
$\mathrm{~F}$ & & & 0,217 \\
\hline
\end{tabular}

\section{Pembahasan}

\section{Pengaruh Kemauan untuk Berubah pada Kewirausahaan Perusahaan}

Hasil penelitian ini menunjukkan bahwa kemauan untuk berubah memiliki pengaruh pada kewirausahaan perusahaan. Fenomena ini dapat terjadi karena dalam 
perusahaan keluarga yang menjadi pengelola inti adalah anggota keluarga, sehingga kemampuan dan kemauan anggota keluarga untuk bersikap terbuka dan tertarik terhadap hal-hal baru menjadi faktor penting dalam meningkatkan kewirausahaan perusahaan. Wulandari (2009) menyatakan semakin baik kemampuan anggota keluarga dalam mengelola sumber daya yang dimiliki perusahaan, maka mereka cenderung akan semakin proaktif dalam mencari peluang-peluang baru, akan lebih inovatif dan kreatif, merespon perubahan yang terjadi pada lingkungan eksternal dengan baik, berani mengambil risiko dan memiliki otoritas untuk menjalankan keputusan perusahaan. Hasil penelitian ini sejalan dengan penelitian yang dilakukan oleh Kellermanns dan Eddleston (2006) serta Weismeier-Sammer (2011) yang menunjukkan bahwa kemauan untuk berubah memiliki pengaruh positif pada kewirausahaan perusahaan.

\section{Pengaruh Keterlibatan Generasi pada Kewirausahaan Perusahaan}

Hasil akhir riset ini menunjukkan tidak adanya pengaruh keterlibatan generasi terhadap kewirausahaan perusahaan. Hal ini membuktikan fenomena keterlibatan banyak generasi dalam pengelolaan perusahaan bukanlah faktor penting dalam peningkatan perilaku kewirausahaan dalam perusahaan keluarga. Harapan yang dimiliki oleh perusahaan keluarga adalah ketika pendiri mempunyai fokus pada usaha keras agar perusahaan dapat berkembang dan bertahan, maka perusahaan akan mulai tumbuh menjadi lebih besar dan kuat dan memasuki tahapan generasi kedua dan extended family, termasuk anak, saudara-saudara, keponakan dan cucu dan akhir nya membentuk the dynasty of family (Majalah Eksekutif, 2014).

Adanya keterlibatan generasi yang berbeda dalam perusahaan keluarga, di sisi lain menurut Mangalandum (2013) berpotensi menimbulkan adanya penyelarasan kepentingan (alignment of interest) dalam bisnis keluarga, termasuk dalam hal pengambilan keputusan bisnis. Hal ini menyebabkan adanya friksi dan konflik antar anggota keluarga yang dilibatkan dalam pengambilan keputusan bisnis tersebut. Friksi antar anggota keluarga ini biasanya semakin tajam begitu perusahaan berlanjut ke generasi kedua, ketiga, dan seterusnya. Hal ini dipicu oleh tidak ada nya keselarasan visi antara generasi lama dan generasi baru dalam perusahaan. Pendiri bisnis yang merupakan generasi lama memiliki tujuan untuk mempertahankan eksistensi bisnis di tengah persaingan yang makin kompetitif, namun generasi baru terkadang memiliki ide-ide baru untuk mengembangkan bisnis keluarga yang di tandai dengan adanya keberanian yang lebih tinggi dalam mengambil risiko, berinovasi dan bersikap proaktif dalam persaingan pasar. Banyak perusahaan keluarga juga kurang memiliki transparansi yang terkadang sengaja diciptakan karena si pendiri tak ingin karyawan (orang luar) mengetahui formula bisnisnya. Karena itu, hanya anggota keluarga yang bisa tahu keseluruhan dari bisnis dan kinerja perusahaan. Walaupun ini dilakukan untuk melindungi rahasia keluarga, akibatnya adalah kinerja kewirausahaan perusahaan tak dapat dioptimalkan karena tak ada sistem yang transparan bagi karyawan-karyawan yang berada di luar lingkaran keluarga. 
Fenomena ini pada akhirnya menunjukkan banyak sedikitnya generasi keluarga yang terlibat secara bersamaan dalam manajemen perusahaan tidak akan mempengaruhi tingkat keberanian perusahaan untuk mengambil risiko, berinovasi dan bersikap proaktif dalam persaingan pasar. Litz dan Kleysen dalam Kellermanns dan Eddleston (2006) menyatakan bahwa kewirausahaan dapat ditemukan pada generasi pertama maupun generasi selanjutnya, sementara ada perusahaan keluarga yang dikelola oleh beberapa generasi kehilangan semangat kewirausahaannya. Hal ini mengindikasikan bahwa seiring berjalannya waktu, generasi pertama tidak selalu memiliki perilaku kewirausahaan yang semakin rendah dan juga multigenerasi tidak selalu memiliki perilaku kewirausahaan yang lebih tinggi. Hasil penelitian ini mendukung penelitian yang dilakukan oleh Kellermanns dan Eddleston (2006), Weismeier-Sammer (2011), serta Eser et al. (2012) menunjukkan bahwa keterlibatan generasi tidak memiliki pengaruh positif pada kewirausahaan perusahaan.

\section{Pengaruh Peluang Teknologi yang dipersepsikan pada Kewirausahaan Perusahaan}

Hasil akhir riset ini menunjukkan tidak adanya pengaruh peluang teknologi yang dipersepsikan terhadap kewirausahaan perusahaan. Hal ini menunjukkan bahwa perusahaan keluarga belum memperhatikan adanya peluang untuk melakukan inovasi produk dengan memanfaatkan perkembangan teknologi yang ada dalam industri mereka. Hasil penelitian ini tidak sejalan dengan penelitian yang dilakukan oleh Kellermanns dan Eddleston (2006) serta Weismeier-Sammer (2011) menunjukkan bahwa peluang teknologi yang dipersepsikan memiliki pengaruh positif pada kewirausahaan perusahaan.

Peluang teknologi sendiri mengacu pada sejauh mana perusahaan keluarga melihat industri mereka menjadi berkembang dalam kesempatan untuk melakukan inovasi dan terobosan teknologi (Zahra 1996). Perusahaan keluarga yang menjadi objek dalam penelitian ini adalah usaha batik yang sebagian besar masih berskala kecil dan menengah yang memiliki kendala dalam akses permodalan. Anggota keluarga yang terlibat dalam bisnis cenderung menganggap keberadaan teknologi terbaru (yang berbiaya tinggi) dalam industri mereka kurang begitu urgent untuk diaplikasikan. Perusahaan keluarga juga memiliki keraguan terhadap efektifitas aplikasi dari teknologi baru tersebut untuk mendorong tingkat penjualan produk mereka, padahal investasi yang harus dikeluarkan tentu nya tidak sedikit.

Di samping itu, mereka juga sudah merasa cukup aman karena merasa sudah memiliki pemahaman terhadap kekayaan hayati dan kearifan lokal yang dianggap menjadi point of uniqueness yang sulit ditandingi oleh kompetitor. Keunggulan lokal ini diantaranya: pengetahuan yang mendalam terhadap pasar dan konsumen lokal; penggunaan bahan hayati lokal; serta relasi bisnis yang unik dengan partner lokal; dan sebagainya. Perusahaan keluarga cenderung merasa cukup dengan hal itu tanpa harus 
repot-repot "bermain" dengan risiko inovasi dan penggunaan teknologi terbaru yang berbiaya tinggi untuk meningkatkan penjualan produknya.

\section{Pengaruh Perencanaan Strategis pada Kewirausahaan Perusahaan.}

Hasil penelitian ini menunjukkan bahwa perencanaan strategis berpengaruh pada kewirausahaan perusahaan. Perusahaan keluarga yang memiliki tingkat perilaku kewirausahaan yang lebih tinggi, memiliki strategi yang berimplikasi pada orientasi kewirausahaan. Penelitian menunjukkan bahwa perusahaan yang lebih memiliki sikap kewirausahaan terus berupaya mengikuti perubahan dan menyebabkan perubahan dalam lingkungan mereka melalui perencanaan strategis (Miller \& Friesen 1982). Perencanaan strategis dapat memberikan tujuan kepada anggota keluarga yang terlibat dalam pengelolaan perusahaan keluarga dan menyalurkan upaya mereka menuju partisipasi yang lebih besar dalam proses kewirausahaan perusahaan (Kellermanns \& Eddleston 2006). Hasil penelitian ini mendukung hasil penelitian Weismeier-Sammer (2011) dan Eser et al. (2012) yang menunjukkan bahwa perencanaan strategis berpengaruh positif pada kewirausahaan perusahaan.

\section{SIMPULAN, KETERBATASAN DAN SARAN}

Variabel anteseden dari kewirausahaan perusahaan adalah kemauan untuk berubah dan perencanaan strategis, sedangkan keterlibatan generasi dan peluang teknologi yang dipersepsikan tidak berpengaruh pada kewirausahaan perusahaan. Hasil penelitian ini menunjukkan adanya konsistensi dengan hasil penelitian sebelumnya (Kellermanns \& Eddleston 2006; Weismeier-Sammer 2011; Eser, Demirbağ, \& Yozgat 2012) tetapi juga terdapat satu perbedaan dengan penelitian sebelumnya, yaitu pengaruh peluang teknologi yang dipersepsikan pada kewirausahaan perusahaan. Dalam penelitian yang dilakukan oleh Kellermanns dan Eddleston (2006) serta Weismeier-Sammer (2011) menunjukkan bahwa peluang teknologi yang dipersepsikan memiliki pengaruh positif pada kewirausahaan perusahaan, sedangkan pada penelitian ini tidak berpengaruh. Ketidak konsistenan ini memberikan peluang penelitian selanjutnya untuk melakukan pengujian dengan menambahkan variabel moderasi agar memperjelas pengaruh peluang teknologi yang dipersepsikan pada kewirausahaan perusahaan.

Penelitian ini juga memiliki keterbatasan, yaitu setiap perusahaan hanya diwakili oleh 1 orang responden, sehingga dimungkinkan kurang dapat mewakili realitas perusahaan karena satu responden terkadang memberikan informasi yang over atau under dari fenomena tertentu. Penelitian selanjutnya sebaiknya menggunakan multiple respond (lebih dari satu responden untuk mewakili setiap perusahaan), sehingga diperoleh informasi yang lebih akurat. Selain itu, penelitian selanjutnya sebaiknya memperluas wilayah penelitian dan juga dapat membandingkan beberapa industri sehingga konsep yang dimodelkan dapat ditingkatkan generalisasinya dan memberikan gambaran yang lebih luas mengenai kewirausahaan di level perusahaan 
keluarga.

Hasil penelitian ini juga memberikan implikasi bahwa untuk meningkatkan perilaku kewirausahaan di level perusahaan dapat dilakukan dengan cara meningkatkan kemauan untuk berubah anggota keluarga yang terlibat dalam pengelolaan perusahaan. Hal ini dapat dicapai, antara lain dengan seringnya mengikuti pelatihan kewirausahaan. Selain itu, perlu perencanaan yang jelas mengenai tujuan dari perusahaan serta cara untuk mencapai tujuan tersebut sehingga akan meningkatkan perilaku kewirausahaan pengelolanya. Disamping itu juga perlu diadakan pertemuan rutin bagi pengelola perusahaan keluarga untuk membahas perkembangan perusahaan.

\section{DAFTAR PUSTAKA}

Borch, Odd Jarl, Morten Huse, dan Knut Senneseth. 1999. "Resource configuration, competitive strategies, and corporate entrepreneurship: An empirical examination of small firms." Entrepreneurship: Theory and Practice 24 (1): 49-70. https://doi.org/Article.

Carney, Michael. 2005. "Corporate governance and competitive advantage in familycontrolled firms." Entrepreneurship: Theory and Practice 29 (3): 249-66. https://doi.org/10.1111/j.1540-6520.2005.00081.x.

Chirico, Francesco, dan David G. Sirmon. 2010. "Entrepreneurial Orientation and Performance in Family Firms: The Joint Effect of Generational Involvement and Participative Strategy." Strategic Entrepreneurship Journal 979 (1): 1-39.

Eser, Gül, Orkun Demirbağ, dan Uğur Yozgat. 2012. “The Effects of Family-Business Related Characteristics and Strategic Planning on Corporate Entrepreneurship." Procedia - Social and Behavioral Sciences, 2012. https://doi.org/10.1016/j.sbspro.2012.09.1069.

Hatiningsih, P. 2012. "Gairah batik setelah pengakuan.” Majalah Bulanan Batik Indonesia, 2012.

Hitt, Michael A.Nixon, Robert D.Hoskisson, Robert F.Kochhar, Rahul. 1999. "Corporate Entrepreneurship and Cross-Functional Fertilization: Activation, Process and Disintegration of a New Product Design Team." Entrepreneurship: Theory \& Practice 23 (3): 145-67. https://doi.org/Article.

Kellermanns, Franz W., dan Kimberly A. Eddleston. 2006. "Corporate entrepreneurship in family firms: A family perspective." Entrepreneurship: Theory and Practice 30 (6): 809-30. https://doi.org/10.1111/j.15406520.2006.00153.x.

Kellermanns, Franz W., Kimberly A. Eddleston, Tim Barnett, dan Allison Pearson. 2008. "An exploratory study of family member characteristics and 
involvement: Effects on entrepreneurial behavior in the family firm." Family Business Review 21 (1): 1-14. https://doi.org/10.1111/j.17416248.2007.00107.x.

Kudla, Ronald J. 1980. "The Effects of Strategic Planning on Common Stock Returns." Academy of Management Journal 23 (1): 5-20. https://doi.org/10.2307/255493.

Majalah, Eksekutif. 2014. "Menguak perusahaan keluarga di Indonesia.” Majalah Eksekutif, 2014.

Mangalandum, Rosa Sekar. 2013. "Peralihan generasi tantangan terberat perusahaan keluarga.” Majalah SWA. 2013.

Miller, Danny. 1983. "The Correlates of Entrepreneurship in Three Types of Firms." Management Science 29 (7): 770-91. https://doi.org/10.1287/mnsc.29.7.770.

Miller, Danny, dan Peter H. Friesen. 1982. "Innovation in conservative and entrepreneurial firms: Two models of strategic momentum." Strategic Management Journal 3 (1): 1-25. https://doi.org/10.1002/smj.4250030102.

Salvato, Carlo. 2004. "Predictors of Entrepreneurship in Family Firms." Journal of Private Equity 7 (3): 68-76. https://doi.org/10.3905/jpe.2004.412339.

Short, Jeremy C., G. Tyge Payne, Keith H. Brigham, G. T. Lumpkin, dan J. Christian Broberg. 2009. "Family Firms and Entrepreneurial Orientation in Publicly Traded Firms: A Comparative Analysis of the S\&P 500." Family Business Review 22 (1): 9-24. https://doi.org/10.1177/0894486508327823.

Simanjuntak, Agustinus. 2010. "Prinsip-Prinsip Manajemen Bisnis Keluarga (Family Business) Dikaitkan Dengan Kedudukan Mandiri Perseroan Terbatas (PT).” Jurnal Manajemen dan Kewirausahaan 12 (2): 113-20.

Sirmon, David G., dan Michael A. Hitt. 2003. "Managing Resources: Linking Unique Resources, Management, and Wealth Creation in Family Firms." Entrepreneurship Theory and Practice 27 (4): 339-58. https://doi.org/10.1111/1540-8520.t01-1-00013.

Top, Seyfi, Ozlem Atam, Ercan Oge, dan Serkan Dilek. 2013. "Evaluation of family effects in the context of power, experience and culture on business and management in the family firms." Procedia - Social and Behavioral Sciences, 2013.

Uhlaner, Lorraine M., Franz W. Kellermanns, Kimberly A. Eddleston, dan Frank Hoy. 2012. "The entrepreneuring family: A new paradigm for family business research." Small Business Economics $38 \quad$ (1): 1-11. https://doi.org/10.1007/s11187-010-9263-x.

Weismeier-Sammer, Daniela. 2011. "Entrepreneurial behavior in family firms: A 
replication study." Journal of Family Business Strategy 2 (3): 128-38. https://doi.org/10.1016/j.jfbs.2011.07.003.

Wulandari, A. 2009. "Pengaruh lingkungan eksternal dan lingkungan internal terhadap orientasi wirausaha dalam upaya meningkatkan kinerja perusahaan." Jurnal Pengembangan Wiraswasta 11 (2): 142-52.

Zahra, Shaker A. 1996. "Goverance, ownership, and corporate entrepreneurship: The moderating impact of industry technological opportunities." Academy of Management Journal 39 (6): 1713-35. https://doi.org/10.2307/257076. 